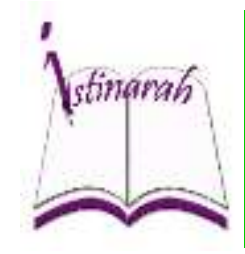

Istinarah: Riset Keagamaan, Sosial dan Budaya, Vol 1 (2), Desember 2019

ISSN : -------- (Print) .............. (Online $)$

Tersedia online di http://ecampus.iainbatusangkar.ac.id/ojs/index.php/istinarah/index

\title{
Penyesuaian Diri dalam Berinteraksi Mahasiswa Mandahiliang di IAIN Batusangkar
}

\author{
Dycki Prayoga *) \\ Institut Agama Islam Negeri \\ Batusangkar \\ Sumatera Barat, Indonesia \\ E-mail: \\ dicky.prayoga@rocketmail.com
}

\section{Irman}

Institut Agama Islam Negeri

Batusangkar.

Sumatera Barat, Indonesia

Email:

$\underline{\text { irman@iainbatusangkar.ac.id }}$

*) Corresponding Author

\begin{abstract}
Abstrak: Permasalahan dalam penelitian ini mahasiswa Mandahiliang asal Paraman Ampalu ketika melakukan penyesuaian diri dalam berinteraksi yang berbeda bahasa dan budaya di lingkungan IAIN Batusangkar, yang bertujuan untuk melihat bagaimana penyesuaian diri dalam berinteraksi mahasiswa Mandahiliang di IAIN Batusangkar. Penelitian ini menggunakan metode deskriptif kualitatif. Pengumpulan data menggunakan wawancara dan semi terstruktur. Teknik analisis data menggunakan analisis Miles dan Hubberman. Hasil Penelitian menemukan (1) Bahwa proses penyesuaian diri dan interaksi yang dilakukan oleh mahasiswa Mandahiliang di IAIN Batusangkar dengan aktif dalam mengikuti berbagai kegiatan di kampus dan berusaha memahami lingkungan sosial budaya yang ada. (2) hambatan komunikasi mahasiswa Mandahiliang ketika berinteraksi adalah bahasa, latar belakang, budaya, dankomunikasi verbal yang sulit dipahami serta sifat meremehkan mahasiswa asli terhadap mahasiswa pendatang (3) Bahasa Universal seperti bahasa Indonesia menjadi pilihan Mahasiswa Mandahiliang untuk berinteraksi dengan mahasiswa lokal.
\end{abstract}

\begin{abstract}
The problem in this study is the Mandahiliang students from Paraman Ampalu when making adjustments in interacting different languages and cultures in the Batusangkar IAIN environment, which aims to see how the adjustment in the Mandahiliang student interaction at Batusangkar IAIN. This study used descriptive qualitative method. Data collection uses interviews and semi-structured. Data analysis techniques using Miles and Hubberman analysis. The results of the study found (1) that the process of adjustment and interaction carried out by Mandahiliang students at IAIN Batusangkar actively participated in various activities on campus and tried to understand the existing socio-cultural environment. (2) Mandahiliang students' communication barriers when interacting are language, background, culture, and verbal communication which are difficult to understand and underestimate the nature of native students against incoming students (3) Universal languages such as Indonesian are the choice of Mandahiliang students to interact with local students.
\end{abstract}

Kata Kunci: Penyesuaian, Interaksi, Komunikasi Budaya 


\section{PENDAHULUAN}

Nilai budaya yang berbeda pada tiap etnik akan menimbulkan sikap dan cara berfikir yang berbeda pula. Demikian juga dalam perilaku yang diambil meskipun dalam masalah yang sama. Perbedaan potensial ini menimbulkan konflik, terutama pada masalah-masalah yang berkaitan dengan interaksi antar etnik. Banyaknya masyarakat yang melakukan transmigrasi atau perpindahan dari suatu tempat yang padat penduduk ke tempat lain yang masih jarang penduduknya. Ketika di tempat yang baru tentu saja masyarakat harus melakukan penyesuaian diri dan adaptasi sosial budaya terutama adaptasi antar etnik. Adaptasi atau penyesuaian yang dilakukan tidak hanya pada masyarakat setempat saja namun juga harus pada lingkungan sekitarnya.

Penyesuaian diri yang buruk ketika melakukan penyesuaian diri dalam berinteraksi bisa mengakibatkan individu melakukan berbagai bentuk tingkah laku yang emosional, tidak terkontrol, sikap agresif dan sebagainya. Seseorang akan mengalami perasaan yang asing serta merasa cemas ketika mengalami perbedaan budaya. Menurut Desmita (2009: 191) Penyesuaian diri adalah suatu konstruksi/bangunan ilmu psikologi yang memiliki arti luas dan komplek serta biasanya melibatkan segala bentuk reaksi individu pada tuntutan dari lingkungan luar maupun dari dalam diri individu sendiri. Dengan kata lain, masalah penyesuaian diri terkait dengan aspek yang menyangkut kepribadian dalam berinteraksi dengan lingkungan dalam dan luar dirinya yang akan mempengaruhi psikis dan psikologis agar bisa bertahan dari segala perbedaan.

Pada penelitian ini, Fenomena yang terjadi pada mahasiswa pendatang asal Paraman Ampalu yang bersuku Mandahiliang di IAIN Batusangkar adalah hidup berkelompok yakni hanya bergaul dan berteman dengan mahasiswa yang berasal dari daerah yang sama, seakanakan mereka merasa tidak percaya diri jika berada dalam komunitas atau kelompok mahasiswa lainya. Dalam perspektif komunikasi timbul pertanyaan bahwa, bagaimana mereka bisa beradaptasi dan menyesuaikan diri 
dengan lingkungan budaya yang baru? Cara-cara apa yang mereka lakukan, agar dengan mudah beradaptasi dengan budaya baru? Secara teoritis bahwa tujuan komunikasi pada dasarnya untuk menciptakan pemahaman atau pengertian bersama

(Good

\section{Understanding).}

Berdasarkan hasil pengamatan yang penulis temukan di lapangan Interaksi antar budaya mempunyai peran dan hambatan yang membuat mahasiswa bisa menilai dan membawa mahasiswa pada perubahan yang lebih baik serta bisa membuat seseorang bisa mengenali dan mempelajari budaya, tradisi serta bagaimana ketika harus bersikap dan berinteraksi dengan sesama baik itu masyarakat ataupun mahasiswa yang berbeda budaya dan dalam proses adaptasi ini peneliti melihat ada mahasiswa asal Paraman Ampalu, Pasaman Barat yang mengalami culture shock pada Mahasiswa IAIN Batusangkar.

Berdasarkan uraian di atas, peneliti tertarik untuk melihat dan menggali lebih dalam serta memahami bagaimana proses yang timbul dari Penyesuaian diri dalam berinteraksi Mahasiswa Mandahililiang di IAIN
Batusangkar yang membuat mahasiswa pendatang tersebut mengalami gegar budaya sehingga menimbulkan konflik-konflik diantara mahasiswa pendatang tersebut. IAIN Batusangkar sebagai institusi pendidikan tinggi yang di favoritkan, merupakan tempat berkumpul mahasiwa dari berbagai daerah, dan tentu saja dengan latar belakang budaya yang beraneka ragam. Dengan kata lain di institusi ini banyak sekali pertukaran budaya yang terjadi dan bisa saja membuat mahasiswa pendatang tersebut mengalami gegar budaya sehingga menimbulkan konflik-konflik diantara mahasiswa pendatang tersebut.

\section{METODE}

Penelitian ini termasuk jenispenelitian deskriptif dengan menggunakan metode pendekatan kualitatif. Menurut Sugiyono (2013: 9) metode penelitian kualitatif adalah metode penelitian yang digunakan untuk meneliti pada kondisi obyek yang alamiah, sebagai lawannya adalah eksperimen. Menurut Bogdan dan Taylor dalam Lexy J. Moleong (2000: 3) mendefenisikan metodologi kualitatif sebagai prosedur penelitian yang menghasilkan data deskriptif 
berupa kata-kata tertulis atau lisan dari orang-orang dan perilaku yang dapat di amati. Sementara itu penelitian deskriptif adalah suatu bentuk penelitian yang ditujukan untuk mendeskripsikan atau menggambarkan fenomena-fenomena yang ada, baik fenomena alamiah maupun rekayasa manusia Lexy J. Moleong (2000: 17).

Tujuan penelitian deskriptif kualitatif untuk memberikan gambaran, dan mendeskripsikan serta mengungkapkan gambaran tentang penyesuaian diri dalam berinteraksi mahasiswa Mandahiliang di IAIN Batusangkar. Latar dan Waktu penelitian, peneliti memusatkan penelitian di IAIN Batusangkar, Waktu dalam penelitian ini pada rentang 30 Januari - 30 Juni 2018.

Dalam penelitian kualitatif, yang menjadi instrumen kunci penelitian adalah peneliti itu sendiri. Menurut Sugiyono (2013: 22) instrumen utamanya adalah peneliti sendiri, namun setelah fokusnya jelas, maka kemungkinan akan dikembangkan instrumen penelitian sederhana, yang diharapkan dapat melengkapi data dan membandingkan dengan data yang ditemukan melalui observasi dan wawancara.

Sumber data dalam penelitian berupa data yang diambil langsung dari objek penelitian seperti Data primer (premier-sources), mencari data langsung ke lapangan dengan sumber penelitian ini adalah Mahasiswa Mandahiliang asal Paraman Ampalu di IAIN Batusangkar. Selain itu peneliti juga menggunakan data Sekunder (secondary-sources), yaitu dengan mencari referensi berupa buku-buku dan jurnal yang berkaitan dengan Penyesuaian diri dalam Berinteraksi (Sugiyono, 2007:103).

Teknik pengumpulan data yang digunakan dalam penelitian kualitatif lebih menekankan pada jenis teknik observasi,yakni metode pengumpulan data dengancara mengamati perilaku dan lingkungan (sosial dan atau material) individu yang sedang diamati. (Anwar Sutoyo, 2009: 73). Observasi yang peneliti lakukan melalui pengamatan secara langsung di lapangan untuk memperoleh data berkaitan dengan Penyesuaian diri dalam Berinteraksi mahasiswa Mandahiliang di IAIN Batusangkar.

Menurut Miles dan Huberman dalam Sugiyono (2013: 246), aktivitas 
analisis data yaitu data reduction atau reduksidata, di sini peneliti mengumpulkan, merangkum, memilih informasi- informasi yang pokok, memfokuskan pada informasi yang penting, di temukan tema dan polanya. Dengan demikian data yang telah diredukasi akan memberikan gambaran yang lebih jelas.

Dalam penarikan kesimpulan peneliti melakukan interprestasi data sesuai dengan konteks permasalahan dari tujuan peneliti. Dari interprestasi yang dilakukan akan diperoleh kesimpulan dalam jawaban masalah penelitian. Dalam penelitian ini uji keabsahan data yang peneliti gunakan adalah dengan triangulasi.

Peneliti menggunakan triangulasi dengan sumber dan metode. Menurut Sugiyono (2013: 225-231) triangulasi dengan sumber berarti dengan cara menguji kredibilitas data dilakukan dengan cara mengecek data yang diperoleh dari Mahasiswa Mandahiliang di IAIN Batusangkar dengan menggunakan triangulasi data sebagai vasilidatas data, yang mana triangulasi ini bertujuan untuk menguji dan menjamin keabsahan data yang dilakukan dengan cara membandingkan data yang diperoleh dari beberapa sumber tentang data. Untuk menguji valid data yang akan peneliti dapatkan dari informan Mandahiliang asal Paraman Ampalu di IAIN Batusangkar, di sini peneliti mengumpulkan keterangan dari beberapamahasiswa Mandahiliang di IAIN Batusangkar.

\section{HASIL DAN PEMBAHASAN}

Berdasarkan hasil penelitian terkait dengan Penyesuaian diri dalam Berinteraksi Mahasiswa Mandahiliang di IAIN Batusangkar, ada beberapa temuan:

Satu: Penyesuaian diri dalam berinteraksi mahasiswa Mandahiliang di IAIN Batusangkar melakukan penyesuaian diri dengan aktif dalam mengikuti berbagai kegiatan di kampus serta berusaha memahami lingkungan sosial budaya yang ada di IAIN Batusangkar untuk mengatasi penyesuaian diri dengan cara berinteraksi dengan mahasiswa lain serta memahami bahasa dan budaya di IAIN Batusangkar.

$$
\text { Dua: Hambatan dalam }
$$
penyesuaian diri mahasiswa Mandahiliang di IAIN Batusangkar 
yaitu sifat meremehkan mahasiswa asli terhadap mahasiswa pendatang yang menjadi hambatan oleh mahasiswa pendatang ketika melakukan penyesuaian diri. Selain itu untuk berinteraksi dengan mahasiswa lain perbedaan bahasa yang sangat signifikan juga membuat interaksi dalam penyesuaian diri mahasiswa Mandahiliang dengan mahasiswa lain terganggu, namun seiring berjalannya waktu mahasiswa Mandahiliang telah mengalami perubahan ketika berbicara sudah memakai logat minang serta mulai mempunyai rasa menghormati juga menjadi pribadi yang mandiri.

Tiga: Penggunaan bahasa verbal mahasiswa Mandahiliang ketika berinteraksi dalam proses penyesuaian diri dapat di simpulkan bahwa mahasiswa Mandahiliang menggunakan bahasa Indonesia dan Minang ketika berinteraksi dengan mahasiswa lain untuk mengatasi kesalahpahaman ketika berinteraksi dengan mahasiswa lain karena perbedaan bahasa yang begitu mencolok antara bahasa mahasiswa pendatang dengan mahasiswa lain di IAIN Batusangkar.

Penyesuaian diri yang dilakukan oleh mahasiswa Mandahiliang asal Paraman Ampalu di IAIN Batusangkar terhadap perbedaan budaya sangat bermacam-macam, Perbedaan budaya menjadi penyesuaian diri mahasiswa Mandahiliang asal Paraman Ampalu dalam menerima, menghargai dan mengatasi permasalahan terhadap penyesuaian diri dilingkungan sosialnya serta hubungan sosial didalam masyarakat ketika berinteraksi tentunya juga memiliki kesalahpahaman dan perbedaan pendapat antara individu satu dengan individu lainnya dalam beradaptasi dan berinteraksi. Mahasiswa Mandahiliang dituntut harus bisa mengelola ketidakpastian dan kecemasan diri dalam diri dan menyesuaikan diri terhadap culture shock. Menurut Ritzer (2010: 289) bahwa kekhususan itu terutama dalam fakta bahwa manusia menginterpretasikan atau mendefenisikan tindakan satu sama lain. Jadi, interaksi manusia di mediasi oleh penggunaan simbol-simbol, oleh interpretasi, atau oleh penetapan makna dari tindakan orang lain.

Penyesuaian diri mahasiswa pendatang asal Paraman Ampalu dalam berinteraksi memilih 
menyesuaian diri melalui aktif dalam mengikuti berbagai kegiatan Unit Kegiatan Mahasiswa (UKM) di kampus serta berusaha memahami lingkungan sosial budaya yang ada di IAIN Batusangkar untuk mengatasi penyesuaian diri dengan cara berinteraksi dengan mahasiswa lain serta memahami bahasa dan budaya di IAIN Batusangkar.

Menurut Burgoon (1979) dalam Morrison (2010: 122) bahwa cara-cara kita menyesuaikan diri dengan orang lain sebagian besar tergantung pada seberapa jauh orang lain melanggar harapan kitauntuk berperilaku. Sebagai lanjutan dari situasi percakapan, dalam lingkup komunikasi interpersonal, setiap orang akan mengalami periode yang sulit ketika menerima ketidak pastian, sehingga orang cenderung membuat perkiraan perilaku orang lain, dan karenanya mahasiswa Mandahiliang akan termotivasi untuk mencari informasi mengenai orang lain di lingkungan baru. Hal ini merupakan fase perencanaan yaitu dimana seseorang masih berada pada kondisi asalnya dengan menyiapkan segala sesuatunya, mulai dari fisik hingga mental, termasuk kemampuan berkomunikasi yang nantinya akan di gunakan dalam kehidupan sosial barunya. Oleh sebab itu, mahasiswa Mandahiliang dapat memperlajari serta memahami makna dan nilai-nilai sosial yang terjadi didalam budaya baru yang berbeda dengan kehidupan di budaya asalnya.

Informan telah memiliki banyak teman dari daerah yang berbeda-beda maupun dari daerah Batusangkar, disebabkan karena mereka telah merasakan culture shock. mereka sudah mempelajari apa saja yang menjadi kebiasaan-kebiasaan mahasiswadan masyarakat yang ada di lingkungan IAIN Batusangkar, baik kebiasaan yang mudah diterima maupun kebiasaan-kebiasaan yang tidak diterima oleh mahasiswa pendatang, kecuali ada satu informan yang mengatakan bahwa sampai saat ini yang menjadi temannya disini ialah teman dari daerahnya sendiri, dikarenakan dia menarik diri dari lingkungan disebabkan dirinya merasa penolakan dari teman-teman kampus yang hanya menyepelekannya.

Informan sudah mempelajari apa saja yang menjadi kebiasaankebiasaan teman-teman mereka yang 
ada disini, baik kebiasaan yang mudah diterima maupun kebiasaan-kebiasaan yang tidak diterima oleh mahasiswa pendatang, kecuali ada satu informan yang mengatakan bahwa sampai saat ini yang menjadi temannya disini ialah teman dari daerahnya sendiri, dikarenakan dia menarik diri dari lingkungan disebabkan dirinya merasa penolakan dari teman-teman kampus yang hanya menyepelekannya.

Mahasiswa pendatang bisa bersosialisasi dan bergaul dengan mahasiswa-mahasiswa lainnya serta bisa menyesuaikan diri dengan lingkungan disini, mereka akan betah tinggal di Lingkungan IAIN Batusangkar sesuai dengan pendapat Hall (1981) bahwafase penyesuaian diri menjadi fase dalam kehidupan sosial individu yang menggambarkan individu harus pintar menyesuaikan diri serta berinteraksi dan beradaptasi dengan budaya baru serta lingkungan yang jauh berbeda dengan budaya asalnya. Berdasarkan penelitian semua informan menjawab sekarang mereka betah tinggal di Batusangkar, karena yang menjadi alasan mereka betah tinggal disini ialah mereka telah mengalami proses budaya/culture shock yang membuat mereka untuk bisa bertahan, dan saat mereka bisa menyesuaikan diri saat itulah mereka mulai betah tinggal di Batusangkar.

Budaya juga mencakup banyak hal dalam kehidupan social mahasiswa Mandahiliang di IAIN Batusangkar, seperti penggunaan bahasa, cara berkomunikasi, perilaku, adaptasi dan interaksi mahasiswa dalam penyesuaian diri di lingkungan baru perilaku dalam hal ini Morissan (2013) mengatakan penyesuaian diri merupakan unsur-unsur interkultural adaptasi terhadap gaya komunikasi individu. Gaya merupakan tingkah laku individu atau perilaku komunikasi individu (Morissan, 2013). Oleh sebab itu, penyesuaian diri dan perilaku individu dalam beradaptasi dapat dikatakan terjadi karena dimensi perseptual, kognitif, dan perilaku diri individu dalam mengkonsepkan diri terhadap culture shock dan perbedaan budaya.

Komunikasi nonverbal banyak digunakan mahasiswa Mandahiliang untuk bisa mengekspresikan perasaan mereka melalui mimik wajah, gerakan kepala dan tangan, serta membantu 
mereka dalam berkomunikasi dengan mahasiswa lokal khususnya saat berinteraksi awal ketika sampai di Batusangkar.

Mahasiswa baru yang belum lama tinggal di Batusangkar atau kurang lebih enam bulan, sangat banyak menggunakan bahasa Universal, bahasa Universal sering kali digunakan oleh mahasiswa Mandahiliang untuk membantu mereka menjelaskan hal-hal yang mereka sampaikan ketika berinteraksi yang mana tidak banyak mahasiswa lokal yang tinggal di IAIN Batusangkar yang paham dengan bahasa Mandahiliang.

Mahasiswa Mandahiliang ketika bersosialisasi dan bergaul dengan mahasiswa-mahasiswa lainnya dengan memakai bahasa Universal yang bisa dipahami mahasiswa lokal. Hal ini sejalan dengan Harper dalam (Fadillah: 2017), mengatakan kendala bahasa merupakan keterbatasan dalam budaya efektif kurangnya pengetahuan serta cara bicara kelompok tertentu dapat mengurangi tingkat pemahaman diri mahasiswa dengan individu lainnya dalam berkomunikasi.

Setiap mahasiswa Mandahiliang ketika bersosialisasi dan bergaul dengan mahasiswa-mahasiswa lain akan memakai bahasa Universal yang bisa dipahami mahasiswa lokal, Hal ini merupakan faktor komunikasi yang sangat penting dalam berkomunikasi. Selain itu, penggunaan bahasa yang universal dapat membuat suatu pengertian terhadap bahasa yang mendorong cara-cara dan nilai-nilai pemahaman mengenai suatu wacana percakapan dalam berkomunikasi serta konsep diri yang dibawa oleh mahasiswa Mandahiliang dalam berperilaku dan bersikap terhadap culture shock merupakan faktor penyesuaian diri dalam berkomunikasi dan berinteraksi.

Komunikasi dan interaksi simbolis mahasiswa Mandahiliang sangat penting dalam kehidupan sosial dan cara berpikir individu mengenai diri, pikiran, serta masyarakat dalam memberikan banyak kontribusi terhadap kehidupan sosial individu dengan budaya baru agar tidak terjadi kesenjangan sosial dan culture shock yang berlebih. Kendala yang dihadapi oleh mahasiswa Mandahiliang asal Paraman Ampalu antara lain bahasa yang berbeda, sikap serta perilaku 
mahasiswa dan masyarakat sekitar IAIN Batusangkar, dan lingkungan yang tidak mendukung menyebabkan gejala culture shockatau perbedaan budaya.

Oleh sebab itu, mahasiswa pendatang harus pintar mengatasi dan menghadapi gejala culture shock didalam kehidupan sosial yang baru serta mempelajari dan memahami perbedaan budaya yang jauh berbeda dengan budaya asalnya serta proses penyesuaian diri yang tidak sebentar dalam mengenal dan memahami perbedaan budaya terutama culture shock.

\section{KESIMPULAN}

Hasil kajian dan penelitian sederhana ini menggambarkan bahwa: Ketika berinteraksi mahasiswa memilih menyesuaian diri melalui aktif dalam mengikuti berbagai kegiatan Unit Kegiatan Mahasiswa (UKM) di kampus serta berusaha memahami lingkungan sosial budaya yang ada di lingkungan baru untuk mengatasi penyesuaian diri dengan cara berinteraksi dengan mahasiswa lain serta memahami bahasa dan budaya.

Penyesuaian diri mahasiswa pendatang dalam adaptasi sangat diperlukan untuk menjalani kehidupan di lingkungan baru karena banyak sekali dinamika yang terjadi sehingga penyesuaian diri mahasiswa sering mengalami kesulitan, oleh karena itu setiap pendatang yang akan mendatangi tempat baru perlu untuk mencari tahu tentang daerah yang akan di datangi agar tidak terjadi perbedaan budaya yang terlalu signifikan.

Hambatan yang sering di temui ketika berinteraksi yaitu bahasa, latar belakang (tempat tinggal), budaya, dan komunikasi verbal yang sulit dipahami, serta sifat meremehkan mahasiswa asli terhadap mahasiswa pendatang menjadi hambatan yang di alami mahasiswa pendatang ketika melakukan penyesuaian diri. Selain itu untuk berinteraksi dengan mahasiswa lain perbedaan bahasa yang sangat signifikan juga membuat interaksi dalam penyesuaian diri mahasiswa dengan mahasiswa lain terganggu, Walaupun seiring berjalannya waktu mahasiswa akan mengalami perubahan namun setisp mahasiswa yang akan mendatangi daerah atau lingkungan baru, perlu untuk mencari tahu tentang bagaimana daerah yang akan di 
datangi, baik dari segi masyarakatnya, bahasa, maupun budaya.

\section{REFERENSI}

Ahmadi, R. 2014. Metodologi Penelitian Kualitatif. Yogyakarta: Ar-Ruzz Media.

Anwar, S. (2009). Pemahaman Individu, Observasi, Cheklist, Interviu, kuesioner, dan Sosiometri, $\quad$ Yogyakarta: Pustaka Pelajar

Desmita. 2009.Psikologi Perkembangan Peserta Didik. Remaja Rosdakarya: Bandung.

Morissan. (2013). Teori Komunikasi Individu Hingga Massa. Jakarta: PT Prenada Media Group.

Moleong, L. J. (2000). Metodologi
Penelitian Kualitatif. Bandung:

PT Remaja Rosdakarya.

Noor, J. (2013). Metodologi Penelitian Skripsi, Tesis, Disertasi dan Karya Ilmiah. Jakarta: Prenada Media Group. Putera, N. (2012). Penelitian Kualitatif Proses \& Aplikasi. Jakarta Barat: Permata Putri.

Ritzer, George dan J,Goodman, Douglas. 2010. Teori Sosiologi Modern. Jakarta: Prenada Media Group

Sugiyono. (2013). Metode Penelitian Kuantitatif Kualitatif dan $R \&$ D. Cet. 18. Bandung: CV Alfabeta.

-------, (2007). Metode Penelitian Pendidikan. Bandung: CV Alvabeta. 